ИСПОЛЬЗОВАНИЕ ПЕРСПЕКТИВНЫХ ИНТЕЛЛЕКТУАЛЬНЫХ СИСТЕМ УПРАВЛЕНИЯ ВО ВРЕМЯ СОЗДАНИЯ ЕДИНОЙ АВТОМАТИЗИРОВАННОЙ СИСТЕМЫ УПРАВЛЕНИЯ ВООРУЖЕННЫХ СИЛ УКРАИНЫ

\author{
П.П. Ткачук, Д.И. Могилевич, О.К. Климович
}

Статья посвящена вопросу применения перспективных интеллектуальных систем управления во время создания Единой автоматизированной системы управления Вооруженных Сил Украины с иелью достижения качественно нового уровня системы управления и повышения эффективности управления жизнедеятельности, подготовки $u$ применения Вооруженных Сил Украины. Разработаны рекомендации, которые направлены на усовершенствование организации методов работы должностных лии органов и пунктов управления.

Ключевые слова: Единая автоматизированная система управления, автоматизированная система управления, гибридные интеллектуальные системы.

\title{
USE OF PERSPECTIVE INTELLECTUAL CONTROL THE SYSTEM DURING CREATION SINGLE AUTOMATED CONTROL THE SYSTEM OF THE ARMED FORCES OF UKRAINE
}

\section{P. Tkachuck, D. Mohylevych, O. Klymovych}

The article is devoted to the question of application of perspective intellectual control the system during creation of Single automated control system of the Armed Forces of Ukraine with the purpose of achievement high-quality of new level of control system and increase efficiency of management of vital functions, preparation and application of Armed Forces of Ukraine. Recommendations for improvement of organization of officials work on command points are developed.

Key words: single automated control system, automated control the system, hybrid intellectual systems.

УДК $351.824 .11+621$

В.М. Філь ${ }^{1}$, В.О. Юрченко ${ }^{2}$, Ю.О. Фтемов ${ }^{3}$

${ }^{1}$ Національний університет оборони Украӥни, м. Київ

${ }^{2}$ Інститут державного управління у сфері ичивільного захисту, м. Київ

${ }^{3}$ Академія сухопутних військ імені гетьмана Петра Сагайдачного, м. Львів

\section{ПРОБЛЕМИ ЕЛЕКТРОТЕХНІЧНОГО ЗАБЕЗПЕЧЕННЯ В СТРУКТУРНО- ЯКІСНІЙ МОДЕРНІЗАЦІЇ ЗС УКРАЇНИ ТА СИЛ ЦИВІЛЬНОГО ЗАХИСТУ ДЕРЖАВНОЇ СЛУЖБИ УКРАЇНИ З НАДЗВИЧАЙНИХ СИТУАЦЙ}

Проведений аналіз керівних документів з питань електротехнічного забезпечення; визначені проблемні питання подальшої структурно-якісної модернізації ЗС України та Державної служби Украӥни з надзвичайних ситуацій стосовно електротехнічного забезпечення; визначені можливі напрямки їх вирішення та його особливості.

Ключові слова: електротехнічне забезпечення, електротехнічні засоби, енергозбереження, сили цчивільного захисту.

\section{Постановка проблеми}

Питання якісного функціонування всіх структурних складових ЗС України, сил цивільного захисту Державної служби України з надзвичайних ситуацій (ДСНС), а також підприємств, установ та організацій різних галузей національної економіки, зниження рівня аварійності, техногенної безпеки військових об'єктів та промисловості тісно пов'язано 3 системою електропостачання військ та об'єктів як енергетичною основою функціонування будь-яких складових системи, а широке впровадження ресурсозберігаючих технологій дедалі стає актуальнішим. Неможливо сьогодні уявити будь-яку військову частину або аварійно-рятувальний загін, які могли б нормально функціонувати в бойових умовах, в умовах мирного часу, під час ліквідації надзвичайних ситуацій або аварійно-рятувальних та інших невідкладних робіт без наявності енергоносіїв, у тому числі електроенергії. Кількість та показники якості останньої безпосередньо будуть впливати на підтримання постійній готовності військ, зброї та сил цивільного захисту 
ДСНС до виконання завдань за призначенням, а також на безаварійне функціонування різних технологічних процесів.

На сьогодні у ЗС України та силах цивільного захисту ДСНС електротехнічному забезпеченню приділяється недостатньо уваги, а в керівних документах з матеріально-технічного забезпечення, оперативного (бойового) забезпечення не згадується про цей вид забезпечення взагалі. Проблемним питанням на сьогодні також $є$ відсутність настанови 3 електротехнічного забезпечення ЗС України і сил цивільного захисту ДСНС, яка б висвітлювала організацію та порядок електропостачання військ та об'єктів при підготовці та в ході бойових дій (операції) та під час ліквідації надзвичайних ситуацій, здійснення аварійно-рятувальних та інших невідкладних робіт. Настанова 3 інженерного забезпечення ЗС України (затверджена наказом НГШ - ГВК ЗС України від 06.07. 2010 року) тільки включає у переліку основних завдань інженерного забезпечення завдання щодо електропостачання військ та об'єктів і не розкриває суті цього завдання.

\section{Формулювання мети статті}

Як вказується [4], структурно-якісна модернізація військ передбачає проведення створення боєздатного, компактного і мобільного війська, успіх виконання завдань якого буде залежати від енергоозброєності, в т.ч. електротехнічними засобами.

У зв'язку з цим метою статті є визначити (сформулювати) особливості електротехнічного забезпечення, підняти проблемні питання щодо подальшої структурно-якісної модернізації 3С України, сил цивільного захисту ДСНС та визначити можливі напрями їх вирішення.

\section{Виклад основного матеріалу}

Аналіз останніх публікацій свідчить про стійку тенденцію зростання споживання електроенергії в арміях усіх країн. Так, наприклад, встановлена потужність військової енергетики армії США під час війни у В'єтнамі була такою, що на кожного солдата припадало до 2 кВт електроенергії, а добові витрати становили більше трьох мільйонів кВт·год. Підраховано, що за останні $10 \ldots 15$ років, споживання електроенергії загальновійськовими формуваннями країн НАТО збільшилось більше ніж у п'ять разів [1].

Аналіз останніх досліджень показує що центральне виробництво електроенергії (АЕС, ГЕС, ТЕС) у нашій державі складає більш ніж 98\% сумарного вироблення електроенергії [2]. Такий стан означає, що ефективна робота щодо управління військами та силами цивільного захисту може здійснюватися лише зі стаціонарних пунктів управління, за умови безперервного електропостачання від об'єктів державної електромережі, а також укомплектованості військ сучасними автономними електротехнічними засобами, які відповідають характеру сучасного бою.

В рамках реалізації концепції “мобільних місій”, яка базується на балансі мобільності, захисту і вогневих можливостей, істотно зростають вимоги до оперативності, гнучкості та безперервності управління військами, силами та зброєю [4]. В основі їі виконання лежить проектування та стійкість функціонування системи електропостачання, в першу чергу пунктів управління, а також об'єктів озброєння та військової техніки (ОВТ) та сил цивільного захисту. Разом із цим система електропостачання пункту управління (СЕП ПУ) - це сукупність взаємозалежних джерел і перетворювачів електроенергії, ефектричних мереж, розподільчих пристроїв, споживачів, пристроїв керування, контролю й захисту, об'єднаних загальним процесом генерування і перетворення, передачі й розподілу електроенергії буде відігравати вирішальну роль у роботі органів управління. Так, вихід із ладу одного 3 елементів порушує управління військами і силами цивільного захисту та підтримання їх в постійній бойовій готовності, виконанні завдань за призначенням.

Таким чином ефективність управління військами, силами цивільного захисту, об'єктами ОВТ та роботи пунктів управління в сучасних умовах все більше залежить від якості проектування, створення та функціонування системи електропостачання військ в бойових умовах, а в мирний час - під час ліквідації надзвичайних ситуацій, здійснення аварійно-рятувальних та інших невідкладних робіт.

Досвід і практика військ Збройних Сил України та сил цивільного захисту ДСНС щодо експлуатації ET3 в польових умовах під час навчань, виконання завдань в миротворчих операціях на території інших держав $з$ різними кліматичними умовами, при ліквідації наслідків надзвичайних ситуацій техногенного та природного характеру, а також в повсякденній життєдіяльності частин в пунктах постійної дислокації показують низьку техніко-економічну ефективність існуючих ЕТ3, що потребує проведення оцінки їх технічного рівня 3 метою визначення вимог щодо тактико-технічних характеристик та техніко-економічних показників ЕТ3, напрямів їх подальшого розвитку, доцільності проведення модернізації існуючих на озброєнні зразків ЕТЗ, а також проектування та розробки конкурентоспроможних ЕT3 для потреб ЗС України та сил цивільного захисту ДСНС.

Сучасний стан електротехнічних засобів загальновійськового призначення (ЕТЗ ЗВП) (рис.) вказує 
за відсутності виробництва і постачання нових ЕТЗ ЗВП на їх фізичне і моральне застаріння та технічне відставання від однотипних зразків армій провідних країн світу [2].

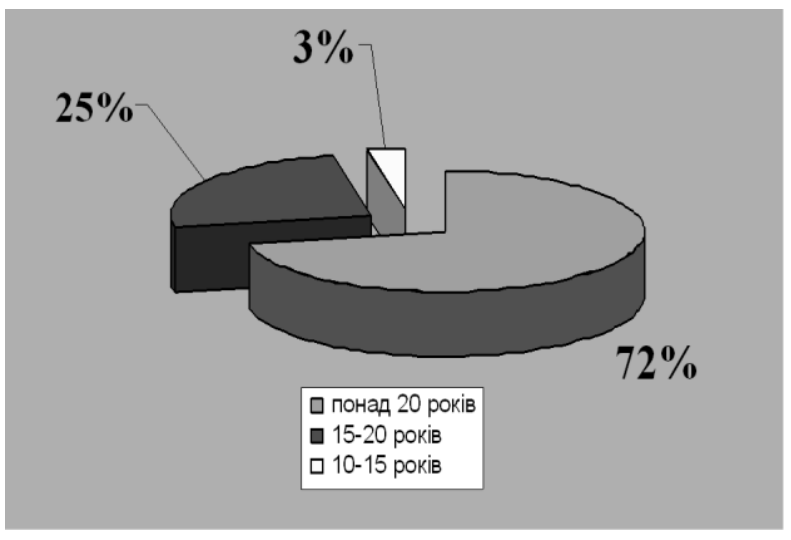

Рис. Терміни зберігання електротехнічних засобів Збройних Сил України

Протягом останніх 15 років підприємствами України було вироблено всього до 30 одиниць інженерної техніки, а такі типи інженерного озброєння, як електростанції, взагалі не вироблялися. Існує проблема, яка має тенденцію до поглиблення це, зростання технічного відставання електротехнічних засобів від однотипних аналогів армій економічно розвинутих держав світу [2].

Крім того, станом на теперішній час на підприємствах, в установах та організаціях різних галузей промисловості енергозабезпечення захисних споруд цивільного захисту (ЗСЦЗ) здійснюється стаціонарними дизельними електростанціями (ЕСДА100/400; 5Е-96-100/100 та ін.) [3,5].

За статистичними даними, більшість 3 них (5560\%) потребують заміни або капітального ремонту. Основними проблемами є: застарілі типи дизельних електростанцій (ДЕС), відсутність справних АКБ, балонів зі стисненим повітрям, відсутність коштів у підприємств, установ, організацій на проведення обслуговування та забезпечення ДЕС пально-мастильними матеріалами [6]. Як результат - не працюють всі інші системи життєзабезпечення захисної споруди (водопостачання, вентиляції, каналізації та ін.), що, в свою чергу, уможливлює здійснення укриття населення у захисних спорудах цивільного захисту в разі загрози або виникнення надзвичайних ситуації.

В бойових умовах потреби всіх видів Збройних Сил України та сил цивільного захисту ДСНС задовольняються в основному електротехнічними засобами загальновійськового призначення. Деяка частина електротехнічних засобів, що використовуються у військах, призначена для живлення тільки конкретних споживачів. До таких засобів відносяться пересувні електростанції та уніфіковані бензоелектричні та дизель-електричні агрегати. Але в мирний час основна частина Збройних Сил та сил цивільного захисту ДСНС споживає електричну енергію від Об'єднаної енергетичної системи України.

Для набуття досвіду i практичних навичок командирів і особового складу у виконанні завдань за призначенням необхідно уже сьогодні передбачати наслідки дефіциту електричної енергії для системи управління військами, систем оперативного, матеріально-технічного, морально-психологічного та медичного забезпечення. Відсутність єдиних i чітких вимог до електропостачання військ, сил цивільного захисту і об'єктів спеціального призначення, методики розрахунку потреби в електричній енергії та електротехнічних засобів, орієнтовних чисельних значень споживаної електроенергії для військових споживачів насамперед зумовлює зниження ефективності застосування військ (сил), зброї та досягнення мети бойових дій (операції), під час ліквідації надзвичайних ситуацій, здійснення аварійнорятувальних та інших невідкладних робіт.

Досвід виконання завдань 5, 6 омбр під час миротворчої операції на території Іраку у складі багатонаціональних сил показав низьку оснащеність електротехнічними засобами, що призвело до появи дефіциту електроенергії близько 1500 кВт. Об'єктивними причинами появи дефіциту електроенергії були: відсутність електроенергії промислового виробництва; кліматичні умови; оснащення підрозділів бригади потужними засобами зв'язку, ПЕОМ та іншою офісною технікою, кондиціонерами та побутовими пристроями, що раніше не враховувавлись при розгортанні пунктів управління та підрозділів забезпечення.

Необхідно підкреслити і тенденцію збільшення енергоозброєності як окремого солдата на полі бою (використання GPS-навігаторів, систем обміну інформації, пристроїв нічного бачення та ін.), так і зміни в оснащеності ЕТ3.

\section{Висновки}

Таким чином, проведений аналіз нормативної бази 3 питань електропостачання військ та об'єктів, а також стан експлуатації ЕТЗ у Збройних Сил України дає можливість зробити висновок, що техніко-економічні показники ЕТЗ, які перебувають на озброєнні військових частин, не відповідають вимогам сьогодення, а їхній технічний стан унеможливлює подальше використання в якості резервних (аварійних) джерел електроенергії.

Для підвищення економічної ефективності, надійності електротехнічного забезпечення в сучасних умовах та в розрізі реалізації концепції “мобільних місій” та національної Енергетичної стратегії на 
період до 2030 року, а також як напрям подальших досліджень пропонується здійснити:

розрахунок технічного рівня ЕТЗ, який дозволить спрогнозувати напрями розвитку ЕТЗ;

обгрунтувати тактико-технічні вимоги до перспективних джерел електроенергії;

провести дослідження стосовно електропостачання військ в бою (операції).

\section{Список літератури}

1. Городнов В.И. Электротехнические средства инженерного вооружения: [учеб. для курс. высш. воен. учеб. зав.] / В.И. Городнов, Н.Н. Гончаров, П.В. Янкаускас. М.: Воениздат, 1989. - 368 c.
2. Тищук С. На часі - енергозбереження // Народна армія.-2008. - 6 жовтня - С. 3.

3. Толубко В.Б. Електропостачання $i$ електрообладнання військових об'єктів: [підруч. у 2 ч.] / В.Б.Толубко, Б.Т. Кононов, Б.Ф. Самійленко, М.І. Григоров. - Харків.: ХВУ, $1998-4.2-500 c$.

4. Замана В.М. Побудова системи управління (оперативного) перспективного складу Збройних Сил України: [Лекиія] / В.М. Замана. - К.: ГШ ЗСУ, 2012. - 24 с.

Рецензент: д.т.н., с.н.с. М.Ю. Яковлев, Академія сухопутних військ імені гетьмана Петра Сагайдачного, м. Львів.

\section{ПРОБЛЕМЫ ЭЛЕКТРОТЕХНИЧЕСКОГО ОБЕСПЕЧЕНИЯ В СТРУКТУРНО-КАЧЕСТВЕННОЙ МОДЕРНИЗАЦИИ ВС УКРАИНЫ И СИЛ ГРАЖДАНСКОЙ ЗАЩИТЫ ГОСУДАРСТВЕННОЙ СЛУЖБЫ УКРАИНЫ ПО ЧРЕЗВЫЧАЙНЫМ СИТУАЦИЯМ}

В.Н. Филь, В.А. Юрченко, Ю.А. Фтемов

Проведен анализ руководящих документов по вопросам электротехнического обеспечения; определены проблемные вопросы дальнейшей структурно-качественной модернизации ВС Украины и Государственной службы Украины по чрезвычайным ситуачиям относительно электротехнического обеспечения; намечены возможные направления их решения и его особенности.

Ключевые слова: электротехническое обеспечение, электротехнические средства, энергосбережение, сильл гражданской защитыл.

PROBLEMS OF ELECTRO-TECHNICAL SUPPORT OF THE STRUCTURAL-HIGH-QUALITY MODERNIZATION OF UKRAINE'S ARMED FORCES AND THE FORCES OF CIVIL PROTECTION OF STATE SERVICE OF UKRAINE FOR EMERGENCY SITUATIONS

V. Fil, V. Yurchenko, Y. Ftemov

The analysis ofguidelines on electrical welfare has been carried out, issues of the further modernization of the Armed Forces of Ukraine and State service of Ukraine on emergency situations on the electro-technical support have been defined.

Key words: electrotechnical support, electrical equipment, energy saving, forces of civil protection. 